\title{
Discrepant Kisses: The Reception and Remediation of North Korean Children's Performances Circulated on Social Media
}

\author{
DONNA LEE KWON
}

\begin{abstract}
This article explores the burgeoning realm of videos uploaded on YouTube generated from content produced in North Korea otherwise known as the DPRK (Democratic People's Republic of Korea). Through state-sanctioned and individual channels, thousands of videos of North Korean music and dance have been uploaded, some resulting in over 57 million hits on YouTube. Taking a cue from this fascination, I employ digital ethnography to investigate the online reception and remediation of North Korean children's performances alongside their online comments on YouTube. I also draw from fieldwork conducted in North Korea in 2007. Theories that espouse the democratic participatory effects of social media platforms do not apply in North Korea where most of the uploaded material is produced and controlled by the state. Given this, I argue that North Korea's engagement with social media is marked by a profound disjuncture where the majority of videos portray ideological North Korean subjects in an online context where very few North Korean citizens are able to engage with this material as social media. I analyze how this disjuncture plays out as international users respond to and remediate these videos in various ways or by creating mash-ups that subvert their original ideological content.
\end{abstract}

A young North Korean girl in a red, babydoll dress sings a song called "Kiss" (Ppo-ppo) [figure 1]. ${ }^{1}$ Another girl, this time in white, extolls the virtues of the "King Potato" (Wang Kamja). Five North Korean boys and girls—noticeably dwarfed by their guitars—perform a song called "Our Kindergarten Teacher" (Yuch’iwŏn uri sŏnsaengnim) garnering over 57 million views on YouTube. ${ }^{2}$ All three of these memorable children's performances have become subject to intense online reception and have generated various creative and discrepant remediations. In little over a decade, North Korea or the DPRK (Democratic People's Republic of Korea) has gradually asserted more of a presence on social media—uploading videos to YouTube and creating Twitter and Facebook accounts—affording unprecedented glimpses into many aspects of North Korean life. While a handful of YouTube channels featuring North Korean content started to emerge as early as 2006, North Korea's social media forays began to attract broader attention in 2010 when channels such as Uriminzokkiri ("With Our People") and StimmeKoreas ("Voice Koreas") launched, in some cases, in close conjunction with attendant accounts on Facebook and Twitter.

\footnotetext{
${ }^{1}$ I have chosen to use the McCune-Reischauer system in romanizing the Korean language. However, I do make a few exceptions and have chosen to use more widely-known or previously published romanizations with the following: place names, author names, politician names, and YouTube user or channel names.

${ }^{2}$ The video referenced here has been posted by multiple users but the one that has reached over 57 million views by the user named Viral Fill was titled "North Korean children playing guitars (Very Creepy)." Unfortunately, this link is no longer active. A similar example can be viewed with the title "North Korea children playing the guitar Creepy as hell," accessed November 27, 2018, https://www.youtube.com/watch?v=DeGdJgWXJ6Q.
} 


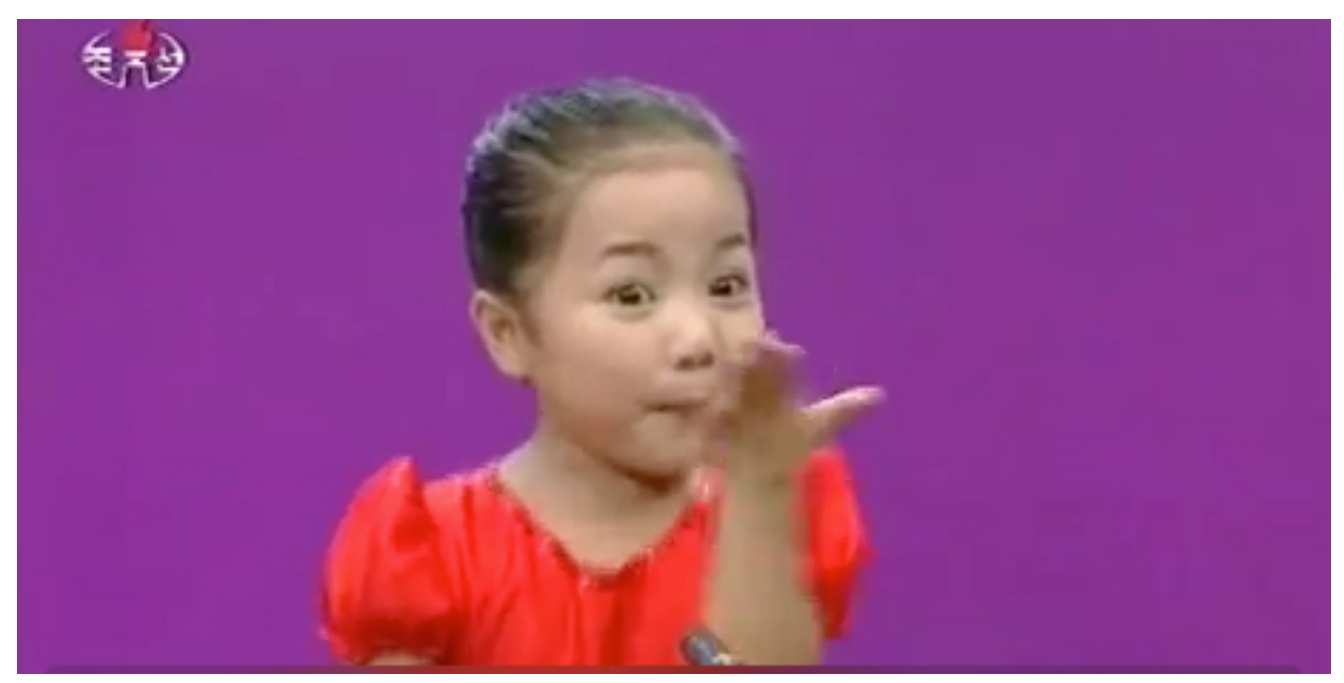

Figure 1: Screenshot of Kim Solmae from video of the song "Kiss" (Ppo ppo or 뽀뽀).

In this article, I will first highlight some of the unique qualities of North Korea's engagement with social media, specifically YouTube. Then, to illustrate how these specificities impact North Korea's social media presence, I focus primarily on children's performances, which have garnered the lion's share of attention. To provide some critical context, I will analyze some of the ideological features of these videos, interpreting their meanings according to the conventions of North Korean political ideology. Drawing upon recent digital ethnography and also from my earlier ethnographic observations from my trip to the DPRK in 2007, the main purpose of this article is to compare the intended political meanings of these videos alongside their international reception and remediation on YouTube. I argue that North Korea's engagement with social media is marked by a profound disjuncture; in other words, the majority of these videos portray ideological North Korean subjects in an online context where very few North Korean citizens are able to engage with this material as social media in the Web 2.0 formats of YouTube, Facebook and Twitter. Even if we interpret these videos solely as external propaganda aimed at non-North Koreans, there is often a disconnect between the material's propagandistic aims and its actual online reception and remediation. Non-North Korean viewers who do have access make sense of this material in diverse and individual ways, often without the historical, linguistic, social, or other contextual tools needed to receive this ideological information in the manner that it was intended. This highly disjunct relationship between the production and reception of North Korean videos on social media makes it a fascinating case study in reception as theorized by Stuart Hall in his seminal 1973 "Encoding and Decoding in the Television Discourse" article. In this article, he lays the foundation for the significance of reception studies by positing that we cannot assume that a "text" will be received as the producers intended because readers will interpret or decode it according to their own life experiences, frames of reference, and background. ${ }^{3}$ In this way, one of the main purposes of this article is to nuance these various points of disjuncture as they play out in the reception and remediation of North Korean children's performances on YouTube.

Within the realm of social media, in particular, I view the concepts of reception and remediation as interrelated. I define reception to encompass the diversity of responses to a particular performance, text,

\footnotetext{
${ }^{3}$ Stuart Hall, "Encoding and Decoding in the Television Discourse," stenciled occasional paper, Media Series No. 7, Centre for Contemporary Studies (University of Birmingham, 1973).
} 
video, sound, image, artwork, or other type of expressive cultural object. In social media contexts, these responses may be as simple as a single individual view or may take the form of a "like/thumb's up" or "dislike/thumb's down" response on YouTube. As simple as these responses are, they gain significance in their repeatability, and have become powerful indicators of an item's popularity or ability to engage people (whether positive or negative). More complex forms of reception include textual responses that can be found in the online comment field, offline interpretations or discussions, and other types of negotiations or engagements with the original object. It is in the last type of reception where remediation begins and where the line between reception and remediation begins to disappear. In defining remediation, I adhere to Jay David Bolter and Richard Grusin's definition of remediation as the "representation," "repurposing," or "refashioning" of a form of media from one medium to another. ${ }^{4}$ In our contemporary world of social media where the re-posting and re-framing of media is commonplace, I argue that remediation can be seen as a hypermediated form of reception.

In analyzing the reception and remediation of North Korean videos of children's performances, I employ techniques of virtual or digital ethnography by approaching websites and digital media as cultural texts and mutually-inflecting digital ontologies, or, in Rene Lysloff and Leslie Gay's term, as "technocultures" of a given community, social system, or institution. ${ }^{5}$ In a more text-specific approach, anthropologists Graham Jones and Bambi Schieffelin have analyzed texting and commenting as rich sites of dialogic and even metalinguistic data that refute the widespread notion that 'YouTube's comment forums are the most 'loud' and 'dumb' corner of the Internet." I will employ a combination of these approaches by examining aspects of production and remediation that can be garnered through audiovisual analysis as well as reception through the comments that accompany each video.

\section{The Unique Digital Terrain of North Korea 2.0}

Although North Korea has started using various types of social media, in order to limit the scope of this article, I focus primarily on YouTube. The majority of North Korean material uploaded onto YouTube stems from North Korean television stations, such as Korean Central Television (KCTV). In November of 2016 and as recently as September 2017, YouTube has begun to crack down on these North Korean social media streams, especially in cases where any potential advertisement revenue might benefit a North Korean entity. Prior to this, however, North Korea Tech originally reported in 2013 that there were sixteen channels on YouTube that were actively uploading North Korean content, with an additional 12 channels that were less active but still accessible. ${ }^{7}$ Of these, some of the more active channels were StimmeKoreas (3213 videos), Rodrigorojo1 (1969 videos), Uriminjokkiri (previously as many as 13,037 videos), 붉은별 TV (Pulgûn Pyôl TV or Red Star TV, 347 videos) and 조선의오늘 (Chosŏnŭi Onŭl or

\footnotetext{
${ }^{4}$ Jay David Bolter, Richard Grusin, Remediation: Understanding New Media (Cambridge: MIT Press, 2000$), 45$.

${ }^{5}$ Ramesh Srinivasan, "Indigenous, ethnic and cultural articulations of new media," International fournal of Cultural Studies 9 , no. 4 (2006): 510, https://doi.org/10.1177/1367877906069899; René T.A. Lysloff and Leslie C. Gay, "Introduction:

Ethnomusicology in the Twenty-first Century," in Music and Technoculture, ed. René T. A. Lysloff and Leslie C. Gay

(Middletown: Wesleyan University Press, 2003), 2-3.

${ }^{6}$ Graham M. Jones and Bambi B. Schieffelin, “Talking Text and Talking Back: 'My BFF Jill' from Boob Tube to YouTube," Fournal of Computer-Mediated Communication 14, no. 4 (July 2009): 1062.

7 "North Korean YouTube List." North Korea Tech, last modified February 8, 2014, http://www.northkoreatech.org/the-northkorean-youtube-list/.
} 
North Korea Today, 6436 videos) ${ }^{8}$ As of 2016, two of the most prolific of these were StimmeKoreas and Uriminjokkiri; together, they were responsible for the uploading of close to 15,000 videos of North Korean content. Not surprisingly, both of these channels were targeted for shutdown in September 2017, although StimmeKoreas appears to be back up to its former capacity with 3480 videos uploaded. ${ }^{9}$

Of these channels, several focus almost exclusively on uploading music and dance videos. These include: DPRK Music (824), VOK216 (128 videos), Songs from the DPRK (200 videos), Ming Kim (156 videos), DPRKMusic1 (31 videos), DPRKconcert (24 videos), Urinore1 (371 videos), DPRKMusic (formerly AnStasyuk, 303 videos), and Chosunmusiccom (267 videos). Although it is no longer one of the more active channels, DPRKMusic is especially significant because its selection of mostly music performance videos has attracted more than 35 million views. ${ }^{10}$ This is a strong indication of the power of music to attract outside views and thereby act as one of the more significant social media windows into North Korean society.

In terms of access in North Korea, it is widely assumed that the state asserts a great deal of control over the content and flow of this media. The majority of the DPRK's citizens do not have access to the Internet. For example, according to Max Fisher, the DPRK has only 1000 or so IP addresses per 25 million people. Fisher writes that "the number of people in North Korea with actual internet access is estimated at a few thousand-most of them government officials." 11 Interestingly, recent reporting suggests that the select North Korean elite and government officials who do have access tend to use the Internet in ways that are similar to users in China or the United States, where common activities include streaming video content, shopping online, browsing the web, and checking their social media accounts. ${ }^{12}$ It should be mentioned that there is a close, state-sanctioned intranet system called Kwangmyong that is available mainly in Pyongyang. As in other places with limited Internet access, North Koreans have also used creative workarounds to accessing online content, such as the use of "sneakernet" or the smuggling of files (text, audio-visual, etc.) by physically moving portable and detachable media (USB flash drives) from one computer or device to another. ${ }^{13}$ Interviews with North Korean refugees suggests that this is fairly widespread. ${ }^{14}$ Even so, there are some obvious differences and limitations with North Korea's engagement with the "sneakernet." For one, the focus of "sneakernet" is primarily on outside content, like South Korean K-pop videos, for example. Second, North Koreans cannot engage and interact "socially" with digital media in real time without Internet access, resulting in less user-generated content and a focus on

\footnotetext{
${ }^{8}$ This data was culled from YouTube as accessed on December 3, 2017, with the exception of the prior figures for the Uriminzokkiri channel, which is now shut down.

${ }^{9}$ The more current number of 3,480 videos uploaded for the Stimmekoreas channel was determined by accessing YouTube on December 15, 2018.

${ }^{10}$ This data was updated and culled from YouTube as accessed on December 15, 2018.

${ }^{11}$ Max Fisher, "Yes, North Korea has the Internet. Here's what it looks like," Vox, March 19, 2015, http://www.vox.com/2014/12/22/7435625/north-korea-internet.

${ }^{12}$ Mike Rogers, "North Korea's internet usage might surprise you," September 13, 2017, New York Daily News, https://www.nydailynews.com/news/national/north-korea-internet-usage-surprise-article-1.3493047; In addition, the notion that DPRK-based channels create channels to raise funds and support is evident in the fact that some North Korean

YouTube channels such as 불근별 TV (Pulgun Pyŏl TV or Red Star TV) list in their “About” pages how to contribute funds through WebMoney services in four currencies: the dollar, ruble, euro, and bitcoin (accessed December 17, 2018, https://www.youtube.com/channel/UCJ7i-yFvuzn9FbUdU77WKcA/about). The purpose of 존선의 오늘 (Chosŏn Today), as described in the "About" page of their YouTube channel, is to display the creativity of hardworking North Koreans as well as their beautiful scenery in order to attract the interest and encouragement of netizens around the world (accessed December 17, 2018, https://www.youtube.com/channel/UCndGz3c8ImJ216C4kZMxaWA/about).

${ }^{13}$ Giovanni Ziccardi, Resistance, Liberation Technology and Human Rights in the Digital Age, (Dordrecht: Springer, 2013$), 221$.

${ }^{14}$ Susan Choney, “North Korea's Internet? What Internet? For most, online access doesn't exist.” NBC News, March 29, 2013, https://www.nbcnews.com/technology/north-koreas-internet-what-internet-most-online-access-doesnt-exist-1c9143426.
} 
the "self" as a subject. When taking into consideration the growing North Korean refugee community, it is important to note that this dynamic is slowly shifting in interesting ways as North Korean refugee personalities, like Yeon-mi Park, begin to assert their presence online.

Another critical issue pertaining to the nature of North Korean social media has to do the question of who is uploading the material and for what purpose. Given that most of the material featuring North Korean musicians and dancers is produced by the state-sanctioned KCTV broadcast channel, the simple answer is the North Korean state. However, the reality is not so simple. Although some YouTube channels have clearer connections to the DPRK state, such as Uriminzokkiri (which has been shut down), many are curated channels from friendly actors of the DPRK, where the relationship between these friends and the state is somewhat unclear. From what I can ascertain from the range of language preferences, it is highly likely that these actors hail from outside of the DPRK, possibly from as far flung locations as Mexico, Russia, Japan, the United States, and China.

This all goes so far as to say that in the world of social media, "the state" is less monolithic than it is presented on other traditional forms of media such as broadcast radio or television. In addition, even with state-sanctioned media, those who curate the channels have some degree of limited power to frame North Korea in various ways. So, for example, some promote an extremely militaristic view of North Korea by only uploading these types of songs, such as those found in the Songs from the DPRK channel (200 videos). In contrast, the aforementioned DPRKMusic curated a more viewer-friendly and appealing window by uploading mainly music and dance videos, often featuring cute children and attractive women performing state-sanctioned virtuosity. Despite this, it is important to note that by virtue of being produced in a highly-controlled state, North Korean content is automatically marked as political. Even when the subject is North Korean beer, noodles, or music, it is all too easy to view this material as propaganda.

Despite these complexities, it appears that North Korea's use of social media on the Internet is meant primarily to direct their state-sanctioned content to the outside world in order to gain and cultivate social and economic support in South Korea, Japan, and China, as well as other parts of the world. ${ }^{15}$ While this makes sense in the North Korean context, there are very few social media theories that account for this kind of state-controlled activity. While many scholars have taken note of the global inequalities of access ${ }^{16}$ and some have started to investigate the ways in which social media is used to support state politics and propaganda (especially in the Middle East ${ }^{17}$ ), few have reckoned with cases as stark as that of North Korea.

Despite North Korea's attempts at control, its social media forays have been troubled. For example,

\footnotetext{
${ }^{15}$ Mike Rogers, "North Korea's internet usage might surprise you," New York Daily News, September 13, 2017, https://www.nydailynews.com/news/national/north-korea-internet-usage-surprise-article-1.3493047; Ben Rossi, "Online activity of North Korea's leaders EXPOSED: how Kim's top men use the internet," Information Age, July 25, 2017, https://www.information-age.com/online-activity-north-koreas-leaders-exposed-kims-top-men-use-internet-123467536/. ${ }^{16}$ E. Gabriella Coleman, "Ethnographic Approaches to Digital Media," Annual Review of Anthropology 39 (2010): 490, https://doi.org/10.1146/annurev.anthro.012809.104945; Matthew Hindman, The Myth of Digital Democracy (Princeton, NJ: Princeton University Press, 2009), 3; Geert Lovink, Zero Comments: Blogging and Critical Internet Culture, (New York: Routledge, 2008), 4, https://www.taylorfrancis.com/books/9781135872151; Trebor Scholz, “Market Ideology and the Myths of Web 2.0," First Monday 13, no. 3 (2008), https://doi.org/10.5210/fm.v13i3.2138.

${ }^{17}$ Rebecca L. Stein, "StateTube: Anthropological Reflections on Social Media and the Israeli State," Anthropological Quarterly 85, no. 3 (2012): 893-916, https://doi.org/10.1353/anq.2012.0045; Alex Fattal, "Introduction: Social Buzz, Political Boom? Ethnographic Engagements with Digital Militancy," Anthropological Quarterly 85, no. 3 (2012): 885-891, https://doi.org/10.1353/anq.2012.0042.
} 
in April of 2013, North Korea found itself the target of the notorious Anonymous hacktivist group who took credit for hacking its Twitter and Flickr accounts as well as compromising sites such as Uriminzokkiri.com. ${ }^{18}$ In addition, certain features of social media such as the "like" feedback and commenting features are especially problematic in terms of control. While one can disable the commenting feature in YouTube, this risks seeming too "closed." Alternatively, someone could monitor comments and delete negative ones, but this is usually too unwieldy an operation for many state-operated channels. ${ }^{19}$ Another critical issue has to do with the ephemeral nature of all digital media where text, audio, and visual data is now subject to extreme mutability, remixing, and other forms of remediation, all of which is further enabled by easy anonymity and hypermobility. ${ }^{20}$

\section{Analysis of Children's Music Performances}

Taking a cue from David Holm's work in China, theater scholar Suk-Young Kim approaches North Korean ideological productions as a "transparent showcase of the regime's intentions" but seeks to go beyond this to analyze how these productions "manipulate and persuade" their subjects. ${ }^{21}$ She goes on to further complicate this by arguing that even within North Korea, the "actual operation of propaganda...is much more discursive" and therefore can be read in various individual ways. ${ }^{22}$ While I cannot at this point nuance this discursive process as it occurs within North Korea, I can look at how this discursive process plays out in reception on YouTube, where most of the viewers are outsiders who are divorced from both the subjects of the videos as well as from DPRK society in general.

Before examining the reception of these videos, however, I will first provide a summary analysis of the features of the production common among these North Korean children's performances, with an eye towards how they attempt to "manipulate and persuade" their subjects, as Suk-Young Kim suggests. North Korean children's performances are largely produced and edited to represent a highly controlled state while highlighting children as model subjects. The children are always impeccably dressed and groomed, wearing matching school uniforms or coordinated costumes. These children perform with few, if any, mistakes. Their manner of performance-including body movements and facial expressions (usually smiles) —are highly stylized and sometimes choreographed. If there is more than one performer, their movements and facial expressions are often synchronized. In these ways, music and dance serve as powerful modes of disciplining young children into "happy" subjects who demonstrate extraordinary technical virtuosity and artistic mastery.

Given the ideological intentions of these videos, some scholars have raised the possibility of these videos being faked with overdubbed sound. While I cannot confirm with certainty whether all the videos in question represent actual live performances, I can respond to this feedback with a few points. First, most of the videos appear to be recordings of live performances that take place on stage with an audience present. In addition, microphones are present on stage, which would suggest that the performers were not

\footnotetext{
${ }^{18}$ Salvador Rodriguez, “North Korea's Twitter, Flickr accounts hacked; Anonymous speaks up,” Los Angeles Times, April 4, 2013, http://articles.latimes.com/2013/apr/04/business/la-fi-tn-north-korea-anonymous-twitter-flickr-20130404.

${ }^{19}$ Rebecca Stein, "StateTube," 902-12.

${ }^{20}$ E. Gabriella Coleman, "Ethnographic Approaches to Digital Media," 494; Henry Jenkins, Convergence Culture: Where Old and New Media Collide (New York: New York University Press, 2008), 2-3; Michael Wesch, "Web 2.0. ... The Machine is Us/Ing Us,” YouTube, January 31, 2007, https://www.youtube.com/watch?v=6gmP4nk0EOE.

${ }^{21}$ Suk-Young Kim, Illusive Utopia: Theater, Film and Everyday Performance in North Korea (Ann Arbor: University of Michigan Press, 2010), 12, https://doi.org/10.3998/mpub.370207.

${ }^{22}$ Ibid.
} 
just syncing to a pre-recorded track. Second, I personally observed young North Korean children perform live in North Korea during my visit to the Mangyŏngdae Children's Palace and other venues in 2007 [figure 2]. Based on this limited experience, it appears that it is quite within the norm for North Korean children to perform at this high of a level. Furthermore, I was surprised also to find that many different kindergartens and elementary schools are represented in the titles of these videos, suggesting that the musical disciplining of young children in North Korea is fairly widespread, at least in the capital of Pyongyang. If this is the case, the motivation to fake these performances would be quite low if there are already many children who can perform at this level. With this said, all of these videos did show some evidence of post-production, so it is possible the sound could have been edited and that the accompanying text could be misleading. Even so, my final point is that regardless of any pre- or post-production editing or the presence of outright syncing to pre-recorded sound, the majority of these children's performances are produced to index or be iconic of live performance in order to showcase aspirational North Korean children as model subjects. ${ }^{23}$ Whether the performances are "actual" or not does not impact their intended ideological message; it only gestures towards the extent to which the state would go in order to achieve this message.

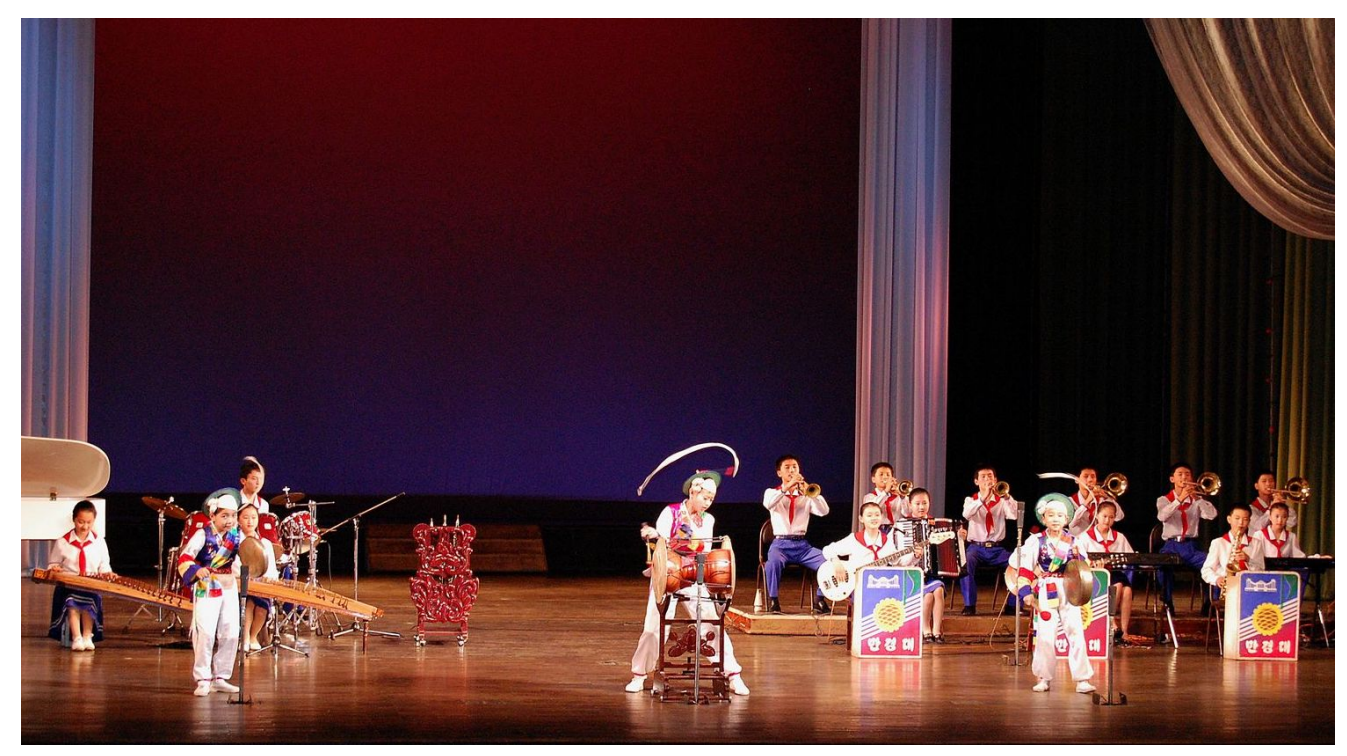

Figure 2: Performance at the Mangyŏngdae Children's Palace, Pyongyang, North Korea (photo by Haeyoung Kim)

In North Korean ideology, children are especially significant because they function in various forms of expressive North Korean media as aspirational subjects within the imagined patriarchal nation-state where Kim Il-Sung-and to a lesser extent, his male successors-are assumed as father figures. ${ }^{24}$

\footnotetext{
${ }^{23}$ I draw here from the Peircean concepts of icon, index, and symbol as the three main categories of signs as framed within various fields of music-making by Thomas Turino in Music as Social Life: The Politics of Participation (Chicago: University of Chicago Press, 2008).

${ }^{24}$ The importance of children as aspirational subjects in North Korea has a long and complex history, some of which can be tracked through the study of North Korean children's literature. Korean studies scholar, Dafna Zur, for example, shows how North Korean writers were influenced by Soviet ideas about targeting and reforming children as ideal socialist subjects through literature. For more about how these ideas developed in early North Korean science fiction for children, see: Dafna Zur, "Let's Go to the Moon: Science Fiction in the North Korean Children's Magazine 'Adong Munhak', 1956-1965," The Fournal of Asian Studies, vol. 73, no. 2 (2014): 327-351, https://doi.org/10.1017/S0021911813002404.
} 
Metaphorically speaking, North Korean subjects are all "eternal children." Suk-Young Kim writes that this "simulation of eternal childhood . . is fleshed out by many hypnotic performance activities." ${ }^{25}$ While there are exceptions, numerous songs performed in these videos reinforce this imagery through their titles, lyrics, and mode of presentation [figures 3 and 4].

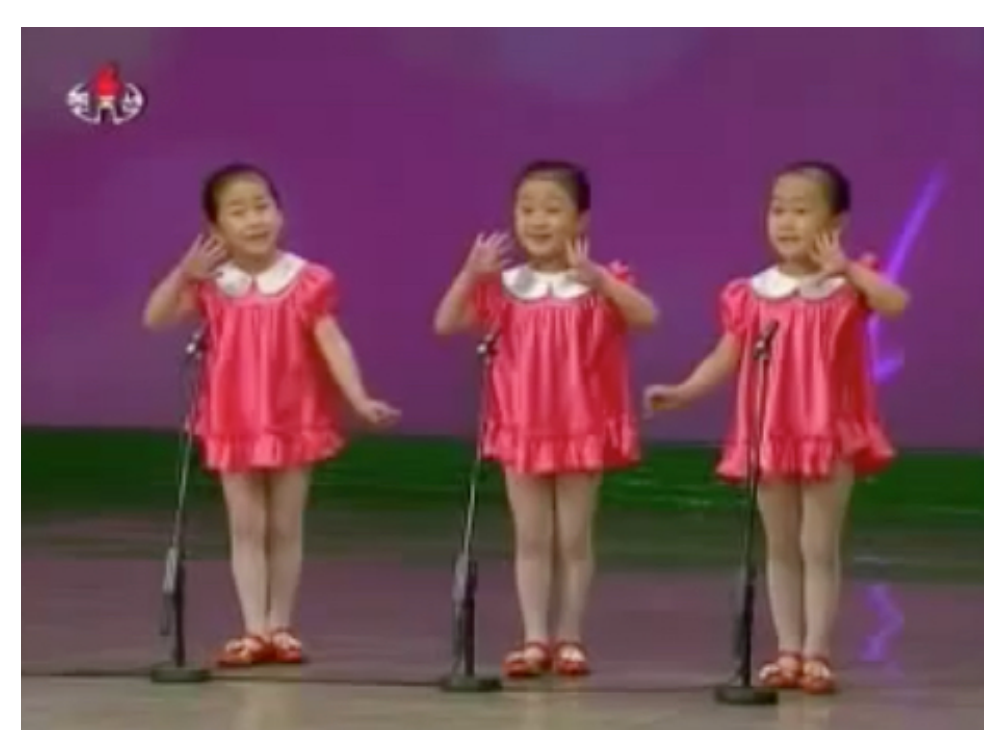

Figure 3: Screenshot of the song "Just Like Your Mother's Heart, the Manbyŏng Plant Blooms Beautifully" (Ŏmŏnim maŭmch'ŏrŏm manbyŏngch'o kopkae p'yŏyo or 어머님 마음처럼 만병초 곱게 펴요)

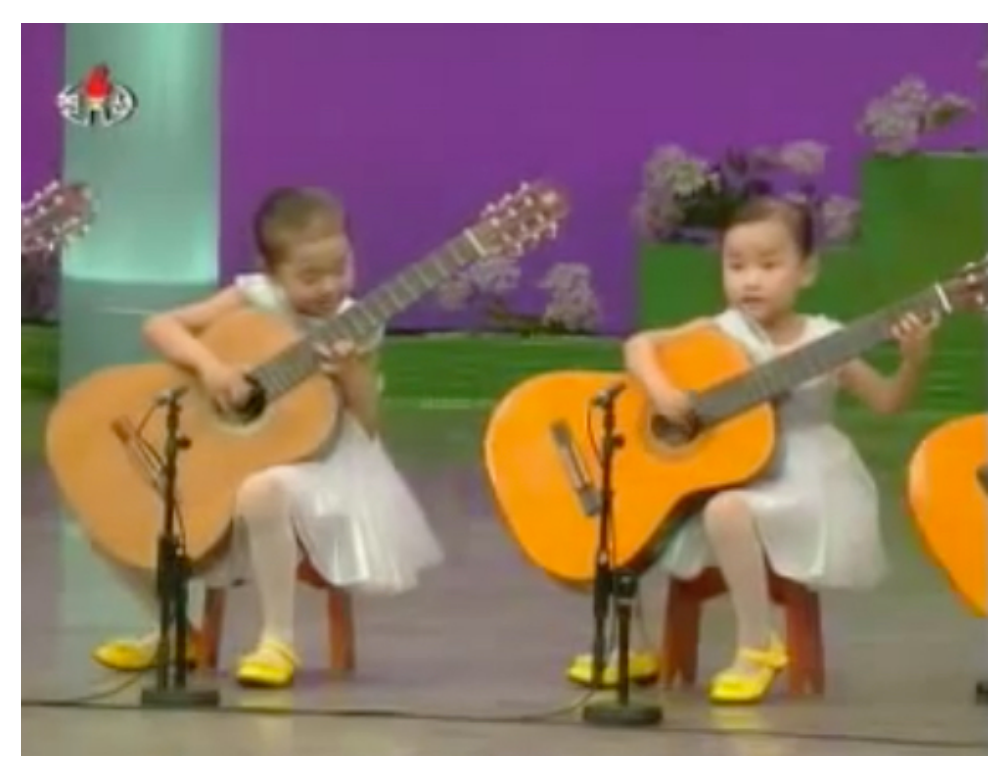

Figure 4: Screenshot of “Our Kindergarten Teacher” (Yuch'iwŏn Ǔri Sŏnsaengnim or 유치원 우리 선생님).

Notably, children usually perform on stage by themselves. Parental or other adult figures are absent or minimized on stage and, if present, the adult figure is usually a woman who will not challenge the implied presence of the North Korean leader as father figure [figure 5]. In addition, these children are further

${ }^{25}$ Suk-Young Kim, Illusive, 144. 
infantilized, first through the disproportionate promotion of extremely young performers (4 to 6 years old is common) and second through their manner of dress and presentation. Girls are often dressed with extremely short, baby-doll-length skirts, even when wearing more traditional dress or chosonot, where ankle-length skirts that modestly cover the knees is more the norm. To take this further, performance clothing styles and hairstyle tendencies in the preschool/kindergarten and early elementary school age group further emphasize a hyper-girlishness that lays an early foundation for the multiple ways in which gender is inscribed in the DPRK. For example, younger girls are often dressed in a more diverse range of bright colors with their longer hair pulled back or braided in different styles, whereas older girls dress in ways that are more uniform. When fleeting glimpses of the audience are included, one will notice that they are almost always seated in accordance to their status, gender, and age, reinforcing a more rigid sense of social order.

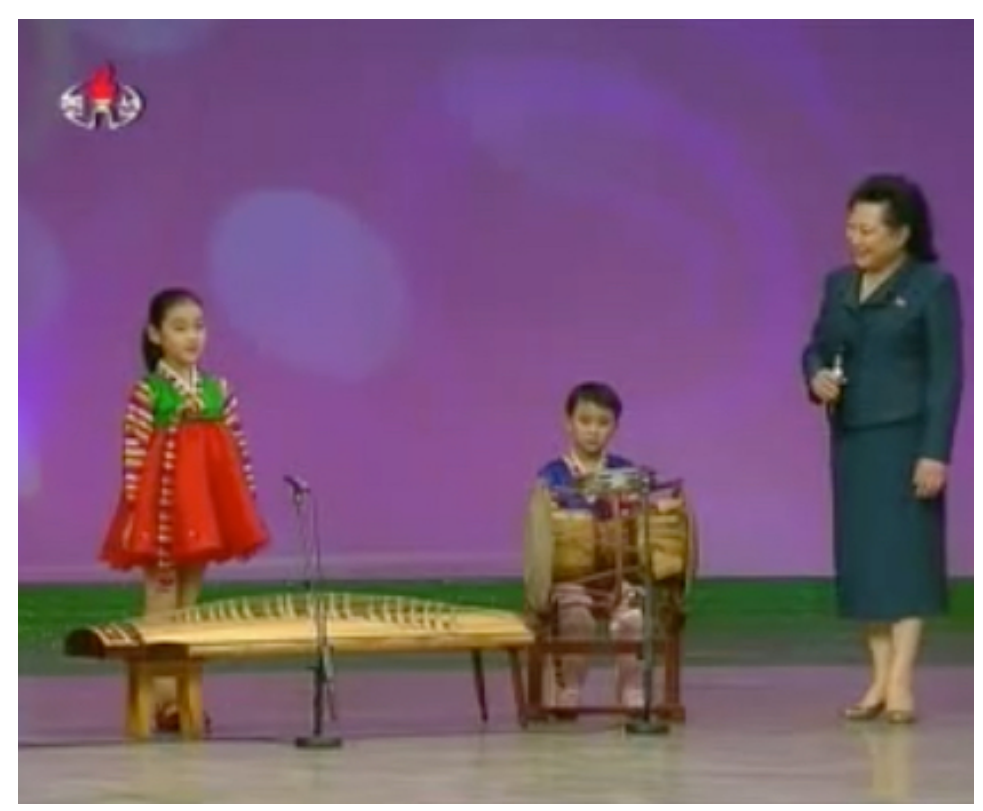

Figure 5: Screenshot of an introduction to the Pyongyang Pongnam Kindergarten, featuring Kim Kumsong.

\section{Analysis of Reception}

Although I have provided only a cursory look into the ideological underpinnings of North Korean children's performances online, the real issue I am trying to gauge is the reception and effectiveness of these videos internationally in an inherently lopsided social media environment. Despite this dynamic, the comment forums do display an inherently "dialogic character" and, as Jones and Scheiffelin note, these forums are rich sites of metalinguistic data, even if they do also enable the "loudest" and "dumbest" voices of the Internet. ${ }^{26}$ This is only compounded by the multi-lingual nature of the forums I looked at, where I came across comments in Russian, English, German, Korean, Italian, Spanish, French, Portuguese, Japanese, Mandarin, Vietnamese, and Thai. Reflecting upon this range of linguistic backgrounds, there was more diversity in the comments than I had anticipated going into this project. In this section, I provide a

\footnotetext{
${ }^{26}$ Graham M. Jones and Bambi B. Schieffelin, "Talking Text and Talking Back,” 1062, https://doi.org/10.1111/j.10836101.2009.01481.x.
} 
discourse analysis of these public comment feeds on YouTube and categorize the range of responses into various tendencies in order to make better sense of the data. In my analysis, I looked at approximately fifty videos and reviewed hundreds of responses to these videos. I tried to consider various languages and represent them here in a manner that reflects this diversity. ${ }^{27} \mathrm{I}$ have chosen to anonymize the user names excerpted below and it should be noted that the tags of "English" or "French" are only indications of the script of the user name and are not a reference to the ethnicity or nationality of the user.

Before embarking on this project, I braced myself to encounter an endless parade of negative comments. To my surprise, I found that positive comments were fairly common. In this sampling below, a substantial contingent of positive commenters simply responded to the artistic or technical accomplishment of the young performers with little critical regard to the political context or implications of the videos.

1_English: $\quad$ North Korean little kids are so talented man!!! They play so good at such a small age!!

2_English: $\quad$ so elegant, voices of angels

3_French: $\quad$ Formidable! Bravo pour la jeune soliste et félicitations à tous les jeunes musiciens.

Amicalement. (Great! Congratulations to the young soloist and to all the young musicians. Sincerely.)

4_German: einfach himmlich diese Kinder (just heavenly, these kids)

5_English: Wonderful, I wish these kids were playing some pieces like Rachmaninoff, Chopin or other!

6_Italian: ma quanto sono bravi questi due ragazzini !! e quanto hanno studiatos!!!!!! (but how good these two kids are !! and how much they have studied !!!!!!)

7_Spanish: BELLISIMA, NIÑOS CON MUCHO TALENTO, ME ENCANTA EL SONIDO MUSICAL, BRAVISSIMA !!!!!!! (BEAUTIFUL, CHILDREN WITH A LOT OF TALENT, I LOVE THE MUSICAL SOUND, VERY GOOD !!!!!!!)

8_Russian: Прекрасны! (Beautiful!)

9_Korean: 아이들이라기에는 놀라울정도로 실력이 좋네요. 소 (The skill level is surprisingly good for kids. $\wedge \hat{\wedge}$ )

Based on the apolitical tone of most of these comments, one might even assume that these commenters were not even aware that these musicians were coming from North Korea. If they did, as with the first commenter (1_English), it seems that they were able to suspend any preconceived notions of the DPRK while surfing content on social media.

At the same time, there are others who are sympathetic with the North Korean state who have responded with somewhat ideologically informed praise of the DPRK, as can be seen in the comments below:

English_10: Serving juche liberates incredible human creative potential!

Ukrainian_11: Long Live North Korea

French_12: $\quad$ Bravo à la digne Nation de la Corée du Nord! Protégeons nos enfants de l'éducation satanique en marche forcée de partout sur cette planète malade. (Congratulations to the worthy

\footnotetext{
${ }^{27}$ The bulk of this data was collected from YouTube in the summer of 2015, and to a limited extent, updated since then, mostly to see which videos and channels were still active. Since these comments were published on a public forum in the YouTube commenting field that accompanies each video, publishing samples of these public comments do not require obtaining informed consent. However, given the sensitive and political nature of some of the comments, I have anonymized the names of the users by numbering them and indicating the script of the language employed in the user name (not necessarily the language of the actual comment, which is sometimes in another language). It should be noted that the tags of "English" or "French" are only indications of the script of the user name and are not a reference to the ethnicity or nationality of the user.
} 
North Korean nation! Let's protect our children from the satanic education from all over this sick planet.)

Demonstrating a deeper awareness of North Korean political ideology, the first commenter (English_10) lauds how the performance demonstrates the creative potential of juche, which is a North Korean concept that roughly translates to a policy of self-reliance and self-determination. In doing so, this commenter connects North Korean children's expression with creativity, which is an unusual, if not subversive stance. The last commenter (French_12) congratulates the North Koreans for doing something right in terms of the musical education of children and condemns other forms of education as "satanic." While this comment may seem extreme, there are many others (see below) who demonstrate some awareness of the North Korean political context and interpret the high level of artistic proficiency demonstrated in these videos as a possible benefit of the North Korean regime. While some commenters are somewhat critical or begrudging, many are quite emphatic in their praise of North Korea's educational system:

Greek_13: Excellent performance of children. Although I'm against totalitarian regimes, I want our children well drilled as in North Korea...ours only play computer games.

English_14: Yes these are most talented kids I have seen in the world. I have searched from France to Thailand not one came close in all of the categories presented to them. North Korea, you have set a good example for the world to learn and that is to teach kids patience, [which] is the key to solving all violence so teach it to your kids at an early stage.

English_15: Absolutely superb. Now this is what children should be doing learning and growing in a positive environment that teaches them how to be knowledgeable instead of learning how to be violent.

Spanish_16: Extraordinario trabajo de enseñanza y aprendizaje musical en la más tierna infancia de estos niños. Debemos interiorizarnos más de esta cultura que ha logrado evitar las esclavizantes tecnologías que han distraido nuestros niños de occidente para robotizarlos y privarlos del arte que tantos logros trae al espíritu humano. Felicitaciones a maestros, padres y especialmente a los niños que ya han alcanzado un nivel superior en la cultura artística. (Extraordinary work teaching and learning music in the early childhood of these children. We must internalize more of this culture that has managed to avoid the enslaving technologies that have distracted our children from the West that robs them and deprives them of the art that brings so many achievements to the human spirit. Congratulations to the teachers, parents and especially to children who have already reached a higher level of artistic culture.)

Korean_17: 저런북한이 어떻게 보면 안쓰럽기도하지만 통일 되면 우리도 북한처럼 재능이 있는 몇몇명은 학교는 자유로 다니고 재은개발에 함써서 재능있는 애들이 많이 나왔으면 좇겠다소. (On the one hand, I feel sorry for North Korea, but if reunification happens, it will be like North Korea where those with talent will be able to go to school freely and it would be good if even more students can emerge by better developing their talents $\wedge \hat{\wedge}$.)

English_18: $\quad$ This is what happens when people bring up their kids without Justin Beiber, Rihanna or Katy Perry.

English_19: $\quad$ wow $i$ wonder if adhd exists in north korea

English_20: This is what happens when you take away their iPhones. Too bad we're going to nuke them. Seems no worse than the pledge of allegiance. Ahhhh lets go to the Walmart fine dining restaurant and have a big mac.

These comments range from serious (Greek_13 to Korean_17) to flippantly cynical (English_18 and English_19) to even sardonic (English_20) in tone. But what seems to emerge here from these 
commenters is perhaps more revealing about their own attitudes about their own youth and systems of education than their views about that of North Korea's. It is almost as if North Korean children emerge as a foil for what is wrong in their own countries while also condemning the influence of popular culture, "enslaving technologies," and the "West."

Some commenters acknowledge the high level of musical mastery but express concern about the human cost.

English_21: kinda cruel...

English_22: $\quad$ All the kids look sleep deprived

English_23: This is the Tiger Mother's dream. Very sad. I wonder what hopes and dreams she might have had that have been thrown on the altar of turning her into an entertainer.

Non-DRPK Koreans, in particular, are very empathetic and see these children as incredibly unfortunate and worry about their welfare in very embodied ways. For example, some of these commenters gesture towards what they assume must have been harsh training in order to achieve this level of performance (Korean_24 and Korean_25). Another user comments on the impoverished appearance of the children's legs (Korean_26), while another expresses their emotional response with the Korean alphabet crying emoticon that looks like this: $\pi \pi$ (Korean_27).

Korean_24: 저 정도면 빡쎄게 연습시켰다는 의미인데... (If they are at that level, it means that they have been made to practice very hard ... )

Korean_25: 와 진짜 대단하다 얼마나 훈련받았으면 저정도까지 할수있는거지 ... 놀랍고 안쓰럽다(Wow, they are really great, how much training they must have received in order to play at that level, in order to play like that ... I'm surprised and saddened)

Korean_26: 하아... 애들 다리 중에서 통통한 다리 하나도 없다 너무 말랐다... (Ha, among the children's legs, there is not one that is healthy/plump, they are too skinny ...)

Korean_27: 힘들겟다... $\pi \pi$ (It must be so hard ... $\pi \pi$ )

Others take the criticism further and frame their comments in a less sympathetic and more grimly cynical direction, often describing North Korean children as exceptionally "creepy," "weird," or "robotic."

English_28: oh this is so weird, are humans or robots?

English_29: they are so creepy, there is no emotion in their faces!!

English_30: Everyone's face look like 30 year old adult. Everyone has no emotion which is not acceptable for democracy.

English_31: Play it Or You Die...

English_32: This is for you Dear Leader, but if I miss a note please don't cut my fingers off.

English_33: I love the music, but watching the smile, gives me a chilling shiver $>\quad<$

Of the various discursive tendencies described above, this type of commentary goes the farthest in terms of distancing or othering the North Korean subject as somehow less than human, and perhaps it is no coincidence that many of these types of comments come from predominantly English speakers. Some extremely hostile commenters go even further and use the comments as a place to "troll" others, turning the forums into a profanity-laced ideological battleground. ${ }^{28}$

While some commenters display knowledge of North Korean or socialist ideology, a good majority of commenters make sense of what they are seeing through their own individual or ideological frames-

\footnotetext{
${ }^{28}$ I have chosen to omit samples of this type of hostile discourse due to its offensive nature and also because I do not think it adds that much more to the discussion at hand.
} 
more often than not missing or disregarding embedded ideological messages or lyrics specific to North Korea. For example, while many described the hyper-infantilization of children as "creepy," few understand its ideological context or history. In addition, for those who see these children as positive evidence of the benefits of a socialist system of education, few comment on the more uncomfortable and yet pervasive references to Kim Il Sung as a god-like father figure. As mentioned previously, these comment forums not only reveal what commenters think about North Koreans but also how they think about themselves in relation to North Koreans. Although the commenting forum does carry the potential of amplifying misunderstandings and knee-jerk opinions, it appears that—on the whole—the format of YouTube does enable a diversified engagement with North Korea, especially in comparison to that which is afforded on conventional media. In this way, North Korea's participation on social media may help cultivate outside support, especially with sympathetic socialist countries or communities-such as the North Korea-affiliated ethnic Koreans living in Japan. ${ }^{29}$

\section{Analysis of Remediated Videos}

Another less common but potentially more effective means of making an impact on shaping opinion is through remediation. One could argue that most North Korean videos are already remediated (according to Bolter and Grusin's definition cited earlier), because the original medium is for television broadcast, clips of which are then excerpted and uploaded onto another medium such as YouTube. However, for the sake of this analysis, I look at further remediations that take place on YouTube. This can take many forms, from the reposting of videos with alternative tags, to the adding of subtitles, to the creation of simple cover videos or more elaborate parody mash-ups that remix audio and visual materials. As alluded to previously, the mere act of a user named Viral Fill reposting a video in 2011 with a new label that reads "North Korean children playing guitars (Very Creepy)," garnered 57 million views. Although this particular highly popular link is no longer available, a similar one with the tag line "North Korean children playing the guitar Creepy as hell” is still available and has attracted approximately 84,100 views as of this writing (see YouTube link 1). The original video and its remediated variants became even more popular because the Seth Rogen- and Evan Goldberg-produced 2014 comedy film, The Interview, about a fictional meeting between two American journalists and Kim Jong-Un, includes a scene that essentially parodies this same performance of North Korean children playing guitar (see YouTube link 2). This demonstrates how even a very minimal form of remediation (re-labeling or re-framing a video) can have far-reaching impacts.

YouTube video 1: http://dx.doi.org/10.3998/mp.9460447.0013.107

YouTube video 2: http://dx.doi.org/10.3998/mp.9460447.0013.107

In response to another popular North Korean children's video called "Ppo Ppo" or "Kiss," I found a few instances of users who re-posted the videos with inventive alternate Korean subtitles, in some cases drawing more than 2.5 million views. In one example (see link below), one user named SongYuBin (송유빈) disrupts the North Korean state-sanctioned intentions of this video in several intriguing ways.

\footnotetext{
${ }^{29}$ Although I have not found significant evidence of North Koreans or North Korean refugees participating in these forums in large numbers, it will be interesting to see how the dynamics may shift if this changes.
} 
First, the user relies on homonyms to construct alternate subtitles with subversive meanings. For example, in place of the culminating lyric of the first verse, "Ŭri appa ppo-ppo-ga chaeil chowa" (우리 아빠 뽀뽀가 제일 좋아) or "Our Daddy's kisses are the best," the user wrote "Ŭri appa ppop-ppo, ha chigyŏwŏ” (우리 아빠 뽑보, 하 지겨워), which could be interpreted as "Our Daddy's kisses, I'm sick of it" with a more exaggerated articulation on the word "kiss." This subverts a sweet sentiment of affection between a daughter and her father into one of annoyance and rejection. Furthermore, instead the first line of the verse, "Naega kowa ppo-ppo" (내가 고와 뽀뽀) or "I am beautiful, kisses," the user writes "Naegachok ppop-po" (내가족 뽑뽀), which means "My family's kisses." This immediately brings the whole family into her hyper-emotional orbit (see figure 6 and YouTube link 3). In a darker interpretation, this same alternate subtitle could also mean "My family was selected," which could gesture in an oblique way towards the inequality of being selected for better access to resources or treatment, or alternatively, for punishment.

\begin{tabular}{|l|l|}
\hline Original Lyrics & New Subtitles \\
\hline $\begin{array}{l}\text { 내가 고와 뽀뽀 우리 아빠 뽀뽀 } \\
\text { I am beautiful kisses, My Daddy's kisses }\end{array}$ & $\begin{array}{l}\text { 내가족 뽑뽀, 우리 아빠 뽑뽀 } \\
\text { My family's kisses, Our Daddy's kisses } \\
\text { 우리 아빠 뽀뽀가 제 일 좋아 } \\
\text { Our Daddy's kisses are the best } \\
\text { 우리 아빠 뽑뽀, 하 지겨워 } \\
\text { Our Daddy's kisses } \\
\text { Ha! I'm sick of it! }\end{array}$ \\
$\begin{array}{l}\text { 우리 아빠 뽀뽀가 제 일 좋아 } \\
\text { Our Daddy's kisses are the best }\end{array}$ & $\begin{array}{l}\text { 우리아빠 뽀! 뽀, 하!!! 지! 겨! 워! } \\
\text { Our Daddy's Kiss! Kiss, } \\
\text { Ha!!! I'm Sick Of It! }\end{array}$ \\
\hline
\end{tabular}

Figure 6: "Kiss” (Ppo-ppo or 뽀뽀), composed by Ham Ki-ch’an and sung by Kim Solmae, Verse 1.

YouTube video 3: http://dx.doi.org/10.3998/mp.9460447.0013.107

The second verse continues along similar lines, substituting the Mommy for the Daddy figure. Here, the user varies the homonym technique and pokes fun of North Korean "otherness" by using alternate spellings to reference a North Korean or Hwanghaedo provincial dialect, as in the spelling of "mommy" (엄마) or "ŏmma” as “omma” (옴마) with a long "o" vowel (See figure 7). More intriguingly, the subtitles continue to mark difference in ever more creative ways by inserting increasingly varied disruptions into the subtitle stream, such as sonic syllables, exaggerated punctuation, Korean texting language and slang, emoticons, symbols, imagined internal commentary, and random behavioral description (see figures 7 and 8). The sonic syllables or vocables introduce sound and noise into the experience by initially reducing the musical accordion accompaniment into a series of "k'ong jjak" (콩짝) syllables (see figure 8). Korean vocables and texting language are further used to reference exaggerated vocal articulations, laughter, and, of course, the lip-smacking sound of kisses. These techniques, along with the imagined internal commentary and behavioral description, emphasize North Korean difference by critiquing the over-the-top expressiveness and quality of hysteria of the performance as a whole. Moreover, the purposely out-of-context use of South Korean texting language conventions, such as linguistic endings that emphasize "cuteness" or aegyo and emoticons, call metalinguistic attention to the 
stark idiomatic differences between North and South Korean modes of expression. Although not all of these interventions can be read as clearly subversive, the cumulative effect of these metalinguistic disruptions is that the subject appears to become more and more unstable as the song goes along. ${ }^{30}$

\begin{tabular}{|c|c|}
\hline Original Lyrics & New Subtitles \\
\hline & $\begin{array}{l}\text { [콩짝콩짝] (K'ong- jjak K'ong jjak) } \\
\text { [똥뾰룰룰로] 눈웃음^^ (Smiling with Eyes) }\end{array}$ \\
\hline \multirow{4}{*}{$\begin{array}{l}\text { 내가 고와 뽀뽀 우리 엄마 뽀뽀 } \\
\text { I am beautiful kisses, My mom’s kisses }\end{array}$} & 내가족 뽀뽀 o3o o3o \\
\hline & My family kisses \\
\hline & 우리 엄마 뽀뽀 o3o o3o \\
\hline & My mom’s kisses \\
\hline \multirow{4}{*}{$\begin{array}{l}\text { 우리 엄마 뽀뽀 제일 좋아 } \\
\text { Our mom's kisses are the best }\end{array}$} & 우리 옴마 뽀뽕 ㅎㅎㅎㅎ \\
\hline & My mom's kisses (옴마 in Hwanghae province \\
\hline & $\begin{array}{l}\text { dialect, cuter version of "kiss" with added } \\
\text { articulation, ha ha ha) } \\
\text { 지겨웡 흫ㅎㅎㅎ }\end{array}$ \\
\hline & I'm sick of it ha ha ha ha ha \\
\hline \multirow{2}{*}{$\begin{array}{l}\text { 우리 엄마 뽀뽀가 제일 좋아 } \\
\text { Our mom's kisses are the best }\end{array}$} & 우리옴마뽀뽀 o3o (옴마 in dialect) \\
\hline & $\begin{array}{l}\text { 하 짉겱웕 (I'm sick of it, but with harsher } \\
\text { articulation) }\end{array}$ \\
\hline
\end{tabular}

Figure 7: “Kiss” (Ppo-ppo or 뽀뽀), composed by Ham Ki-ch’an and sung by Kim Solmae, Verse 2.

\begin{tabular}{|c|c|}
\hline Original Lyrics & New Subtitles \\
\hline & $\begin{array}{l}\text { [폴짝, 풀짝풀짝] [콩짝콩짝콩짝] (percussive } \\
\text { vocables) } \\
\text { [쎄힛] 눈웃음^ (three hits, smiling with eyes) } \\
\text { [뽀뽀의힙을 받아라, 쪼오오오오오오옥] } \\
\text { [뽑뽀!!!!!!!!!](Receive the energy of the kiss, } \\
\text { jjoooook, kiss !!!!) } \\
\text { [너는 나의 달콤한 kiss에 반해버렸지, baby] } \\
\text { 데헤헿헿헤 헿] (You are my sweet kiss, it’s gone, } \\
\text { baby, nonsense vocables) }\end{array}$ \\
\hline
\end{tabular}

${ }^{30}$ There is another version of this same song to which another user has added his/her own subtitles circulating on YouTube, and it is even more extreme and nonsensical than the one analyzed here. 


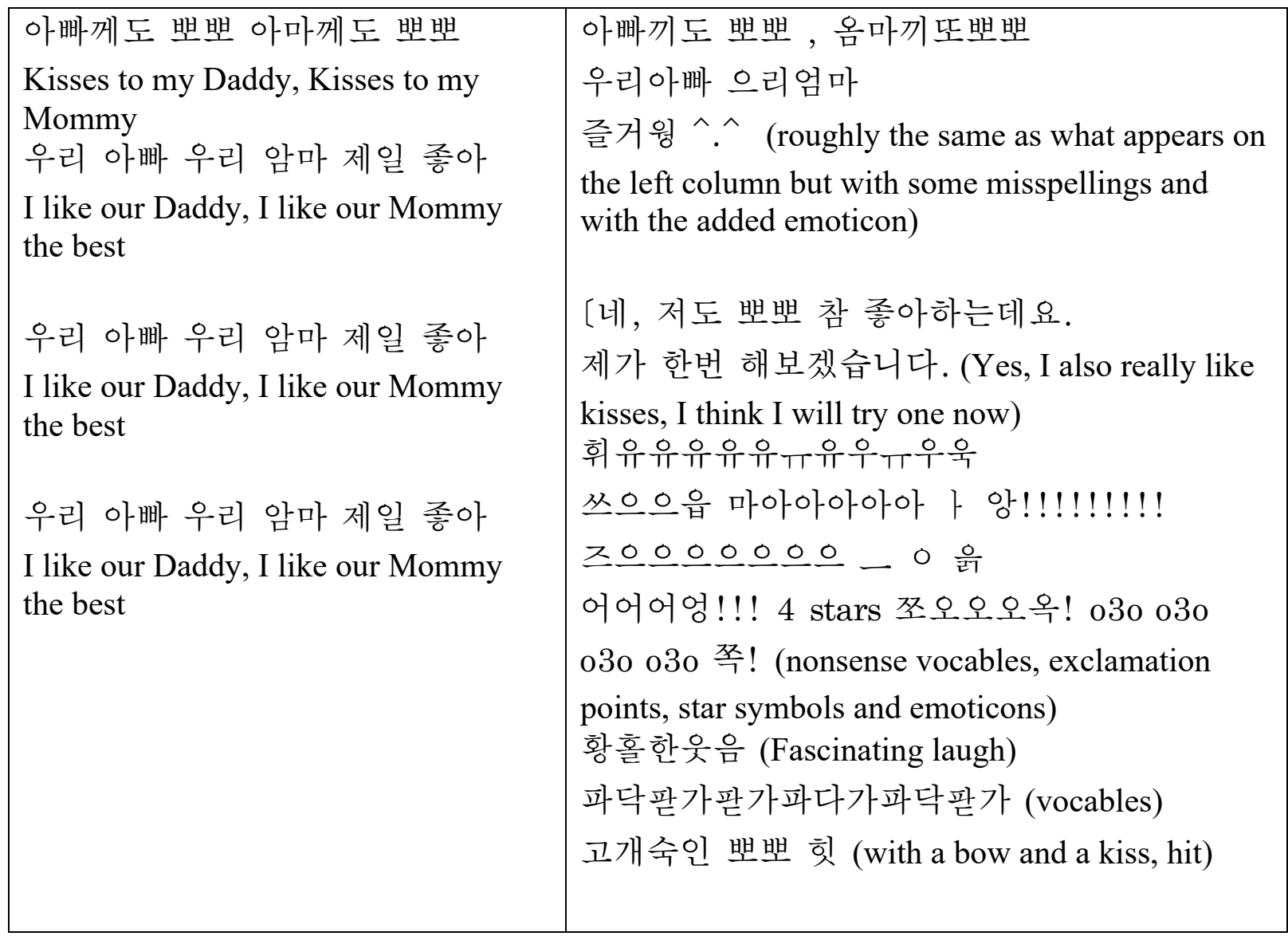

Figure 8: “Kiss” (Ppo-ppo or 뽀뽀), composed by Ham Ki-ch'an and sung by Kim Solmae, Verse 3.

Another interesting phenomenon that has spun out of this "Kiss" video is the creation of lip-sync videos. In one example, a White, presumably North American female teenager wears a red and white gingham dress with her long hair in two messy buns, reminiscent of the popular culture character Princess Leia. ${ }^{31}$ Her eyes are deliberately overexposed as she mimics the "Kiss" video in a flippant parody. In another, a plainly dressed South Asian female and self-described "Big fan : )" performs a remarkably earnest lip-sync. I am particularly struck by her close attention to the nuances of facial expression and hand gestures here that are somewhat resonant with the stylistic conventions of Indian music and dance. If there is parody here, it exists only with a slight wink as if to say, "I know this is trite but I like it anyway" (see figure 9). ${ }^{32}$ This tone is also present in another video response by a White male, who similarly bills himself as Kim Sol Mae's "number one fan." However, with his addition of a shiny black and red kimono and over-the-top gestures, his interpretation veers more into campy exuberance (see YouTube Link 4).

\footnotetext{
${ }^{31}$ The link for the video is entitled "Cover of Kim Sol Mae Vinnie \& Maecy," accessed March 16, 2018, https://www.youtube.com/watch?v=zDW4PnyRQhs\&index=11\&list=PLtIGn EMGnHZo-iyU1BYU91048v8O Yxb.

${ }^{32}$ This video is no longer active, but I have provided a screenshot in figure 9.
} 


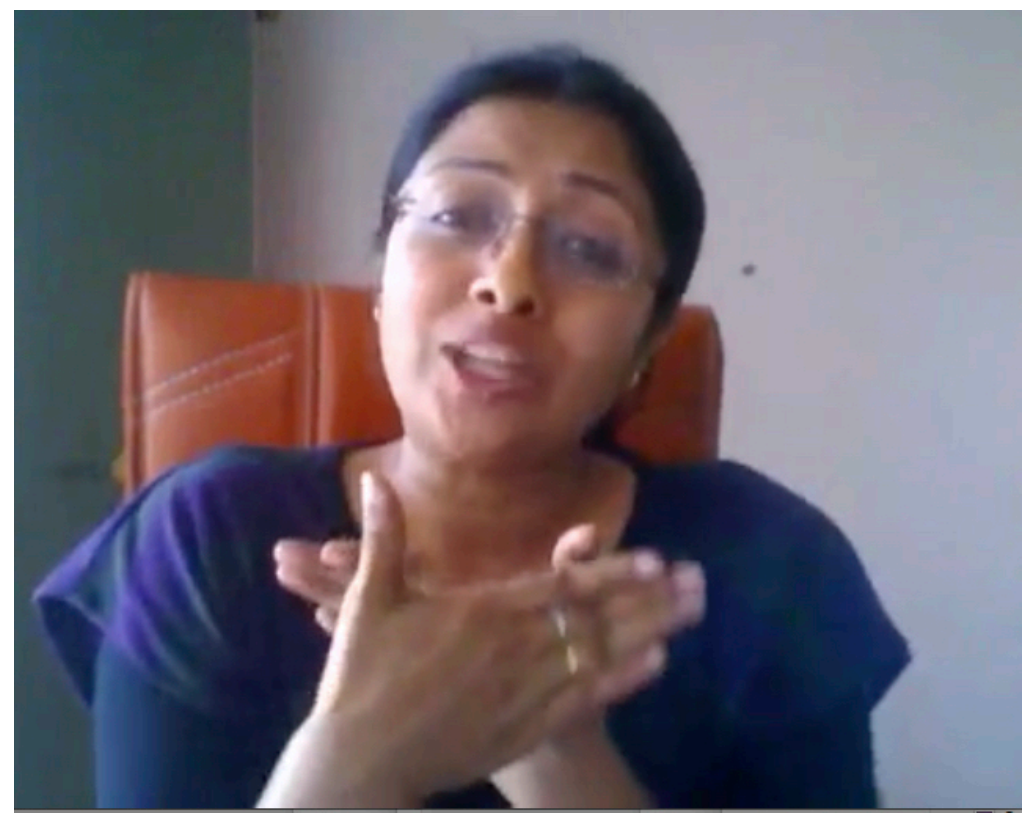

Figure 9: Screenshot of a Parody video of the song “Kiss" (Ppo ppo or 뽀뽀).

\section{YouTube video 4: $\mathrm{http}: / / \mathrm{dx} . \mathrm{doi} . \mathrm{org} / 10.3998 / \mathrm{mp} .9460447 .0013 .107$}

In another form of remediation, a France-based group and YouTube user called Magoyond created a remixed video that edits both the viral guitar-playing children and "Kiss" visuals together with the audio of the djent metal band Meshuggah's best-known song "Bleed" (see YouTube Link 5). On the surface, this intervention is reminiscent of "jamming," which according to Mark Déry is CB (citizens band) radio slang for the "illegal practice of interrupting radio broadcasts or conversations between fellow hams with lip farts, obscenities, and other equally jejune hijinx." ${ }^{33}$ Here, though, the joke is on North Korea. Judging from the YouTube comments, many found this remix to be hilarious and, in the words of one commenter, it was "...the funniest thing I've seen on YT." However, there is a subversive political undertone here, and I argue that this remix could also be interpreted in terms of what Mark Déry further develops as "culture jamming," which he describes as the intentional disruption of the media's power to control through the "manipulation of symbols," often by using the same tools to expose or disrupt this manipulation. ${ }^{34}$ Here, Magoyond interrupts, remixes and ultimately upends the ideological intentions of these videos, so that these cute, well-disciplined children suddenly become exposed as "demonic" subjects - or perhaps victims - of a warped society. With the replacement of the original audio with Meshuggah's unrelenting song, "Bleed," which is a biting commentary on humankind's contradictory and yet symbiotic relationship to violence, the clip gains an aura of oppressive heaviness that runs antithetical to the child-oriented subject matter of the original songs. Although some commenters seem to concur with this darker, lyric-based interpretation, admitting that they do not know whether to laugh or cry for these kids, the truth is that its reception has been varied. While many found this remediation to be cool and clever in its unlikely juxtaposition of content, some Meshuggah fans felt that the "footage is much

\footnotetext{
${ }^{33}$ Mark Dery, "Culture Jamming: Hacking, Slashing, and Sniping in the Empire of Signs," accessed March 16, 2018, http://markdery.com/?page id=154 (originally published in 1993 in the Open Magazine Pamphlet Series).

${ }^{34}$ Dery, "Culture Jamming."
} 
more brutal than the music itself." According to Déry, this is as it should be, as culture jammers are "part artistic terrorists, part vernacular critics" who "introduce noise into the signal as it passes from transmitter to receiver, encouraging idiosyncratic, unintended interpretations." 35

YouTube video 5: $\underline{\text { http://dx.doi.org/10.3998/mp.9460447.0013.107 }}$

\section{Conclusion}

North Korea's engagement with social media has enabled unprecedented levels of international engagement with its state-sponsored media, and I argue that children's performances are a flashpoint for this activity. This is evident in the disproportionately high number of views that they attract in relation to other types of content. To summarize my analysis, I have found that the range of responses is much more diverse, and in some cases, more reflective and self-reflexive than I had anticipated. I was also surprised by the high level of engagement, as evidenced in the large number of views and comments as well as by the intensity of these responses, positive or negative. Interestingly, the more nuanced and critical responses tapped into individual anxieties about the future-as projected onto the Othered North Korean child subject-anxieties about how to best raise and educate children in a politically divisive and competitive world.

As David Novak points out in his landmark article on remediation, "contemporary subjects live much of their lives through media. They reappropriate received materials for widely divergent personal goals, and construct social relations through an intertextual discourse of mediated references." ${ }^{36}$ This certainly is true of the users who remediated North Korean children's performance content that I examined for this article. I would add that the logic of hypermediacy as defined by Bolter and Grusin "as a style of visual representation whose goal is to remind the viewer of the medium" was ever present in the examples I highlighted. ${ }^{37}$ Remediators of North Korean children's performances were able to "remind the viewer of the medium" by calling attention to stark differences in mediums and styles (texting styles, languages, styles and genres of music, performance gestures, and costumes): the more unlikely and clever the juxtaposition, the better the result. In this light, North Korean content works well for remediators in developed, global societies such as the US, given the DPRK's relatively high level of isolation and difference from the rest of the world.

David Novak concludes his article on remediation by drawing on the work of anthropologist Anna Tsing, saying that remediations are not co-productions but are often unequal collaborations that are indicative of "overlapping but discrepant forms of cosmopolitanism" that contribute to a broader global "friction." 38 In the case of North Korea, where access to the Internet is drastically limited, the unequal power dynamic is especially pronounced. Moreover, without many real points of contact or sparks of dialogue, I wonder whether North Korea's social media experiment does enough to create the kind of

\footnotetext{
35 Ibid.

${ }^{36}$ David Novak, “Cosmopolitanism, Remediation, and the Ghost World of Bollywood," Cultural Anthropology 25, no. 1 (2010): 41, https://doi.org/10.1111/j.1548-1360.2009.01051.x.

${ }^{37}$ Jay David Bolter and Richard Grusin, Remediation: Understanding New Media (Cambridge: MIT Press, 2000 ), 272.

${ }^{38}$ Anna Lowenhaupt Tsing, Friction: An Ethnography of Global Connection (Princeton, NJ: Princeton University Press, 2005), 13.
} 
powerful "global connections" that come to life in "friction" in the way that Anna Tsing describes. ${ }^{39}$ Tsing writes that "friction is a reminder of the importance in defining movement, cultural form, and agency" and that "friction is required to keep global power in motion." ${ }^{40}$ She observes that while "friction makes global connection powerful and effective," it can also "get in the way of the smooth operation of global power" and could eventually spur refusal and insurrection. ${ }^{41} \mathrm{I}$ argue that North Korea is a unique case and is less susceptible to the workings of global power. The DPRK is no doubt well-aware of the "friction" that could be unleashed if more North Koreans were able to travel and/or access the Internet. This may explain North Korea's vacillating relationship with social media, where as recently as spring of 2018, reporters have noticed a marked drop-off in use, after a period of noteworthy increase among North Korean elites. ${ }^{42}$

While many outside of North Korea are free to remediate and comment upon videos, the North Korean children featured in these videos cannot further elaborate upon or interpolate their stories in the social media environment. In fact, their silence outside the frame of these videos is disconcerting for many commenters as they speculate about the fates of these children. I am also struck by how difficult it is for many viewers to see these children as just children and not as politicized, ideological subjects. Although it is outside the scope of this project, it is possible that combined with other forms of media engagement on the ground through the "sneakernet" or the exchange of media smuggled on USB drives in North Korea or among North Korean refugee communities, that a broader global friction is beginning to take hold to make a larger impact on North Koreans and non-North Koreans alike.

\section{Bibliography}

Bolter, Jay David, and Richard Grusin. Remediation: Understanding New Media. Cambridge: MIT Press, 2000.

Coleman, E. Gabriella. "Ethnographic Approaches to Digital Media.” Annual Review of Anthropology 39 (2010): 487-505. https://doi.org/10.1146/annurev.anthro.012809.104945.

Dery, Mark. "Culture Jamming: Hacking, Slashing, and Sniping in the Empire of Signs," accessed March 16, 2018. http://markdery.com/?page_id=154 (originally published in 1993 in the Open Magazine Pamphlet Series).

Fattal, Alex. "Introduction: Social Buzz, Political Boom? Ethnographic Engagements with Digital Militancy." Anthropological Quarterly 85, no. 3 (2012): 885-891. https://doi.org/10.1353/anq.2012.0042.

Fisher, Max. "Yes, North Korea has the Internet. Here's what it looks like," Vox, March 19, 2015. http://www.vox.com/2014/12/22/7435625/north-korea-internet.

Hall, Stuart. "Encoding and Decoding in the Television Discourse." Stenciled occasional paper, Media Series No. 7, Centre for Contemporary Cultural Studies. University of Birmingham, 1973. Hindman, Matthew. The Myth of Digital Democracy. Princeton, NJ: Princeton University Press, 2009. Jenkins, Henry. Convergence Culture: Where Old and New Media Collide. New York: New York University Press, 2008.

\footnotetext{
${ }^{39}$ Tsing, Friction, 6.

${ }^{40}$ Ibid.

${ }^{41}$ Ibid.

${ }^{42}$ Ellen Tanman, "Why are internet users in North Korea abandoning Western social media?," Silicon Republic, April 25, 2018, https://www.siliconrepublic.com/enterprise/north-korea-social-media.
} 
Jones, Graham M., and Bambi B. Schieffelin. "Talking Text and Talking Back: 'My BFF Jill' from Boob Tube to YouTube.” Journal of Computer-Mediated Communication 14, no. 4 (July 2009): 1050-79. https://doi.org/10.1111/j.1083-6101.2009.01481.x.

Kim, Suk-Young. Illusive Utopia: Theater, Film and Everyday Performance in North Korea. Ann Arbor: University of Michigan Press, 2010. https://doi.org/10.3998/mpub.370207.

Lovink, Geert. Zero Comments: Blogging and Critical Internet Culture. New York: Routledge, 2008. https://www.taylorfrancis.com/books/9781135872151.

Lysloff, René T.A., and Leslie C. Gay, "Introduction: Ethnomusicology in the Twenty-first Century.” In Music and Technoculture, edited by René T. A. Lysloff and Leslie C. Gay, 1-22. Middletown: Wesleyan University Press, 2003.

North Korea Tech. "North Korean YouTube List.” Last modified February 8, 2014. http://www.northkoreatech.org/the-north-korean-youtube-list/.

Novak, David. "Cosmopolitanism, Remediation, and the Ghost World of Bollywood." Cultural Anthropology 25, no. 1 (2010): 40-72. https://doi.org/10.1111/j.1548-1360.2009.01051.x.

Rodriguez, Salvador. "North Korea's Twitter, Flickr accounts hacked; Anonymous speaks up," Los Angeles Times, April 4, 2013. http://articles.latimes.com/2013/apr/04/business/la-fi-tn-north-koreaanonymous-twitter-flickr-20130404.

Rogers, Mike. "North Korea's internet usage might surprise you," New York Daily News, September 13, 2017. https://www.nydailynews.com/news/national/north-korea-internet-usage-surprise-article1.3493047.

Rossi, Ben. "Online activity of North Korea's leaders EXPOSED: how Kim's top men use the internet," Information Age, July 25, 2017. https://www.information-age.com/online-activity-north-koreasleaders-exposed-kims-top-men-use-internet-123467536/.

Scholz, Trebor. "Market Ideology and the Myths of Web 2.0." First Monday 13, no. 3 (2008). https://firstmonday.org/article/view/2138/1945. https://doi.org/10.5210/fm.v13i3.2138.

Srinivasan, Ramesh. "Indigenous, ethnic and cultural articulations of new media." International Journal of Cultural Studies 9, no. 4 (2006): 497-518. https://doi.org/10.1177/1367877906069899.

Stein, Rebecca L. "StateTube: Anthropological Reflections on Social Media and the Israeli State." Anthropological Quarterly 85, no. 3 (2012): 893-916. https://doi.org/10.1353/anq.2012.0045.

Tanman, Ellen. "Why are internet users in North Korea abandoning Western social media," Silicon Republic, April 25, 2018. https://www.siliconrepublic.com/enterprise/north-korea-social-media.

Tsing, Anna Lowenhaupt. Friction: An Ethnography of Global Connection. Princeton, NJ: Princeton University Press, 2005.

Turino, Thomas. Music as Social Life: The Politics of Participation. Chicago: University of Chicago Press, 2008.

Wesch, Michael. "Web 2.0. ... The Machine is Us/Ing Us.” YouTube, January 31, 2007, https://www.youtube.com/watch?v=6gmP4nk0EOE.

Zur, Dafna. "Let's Go to the Moon: Science Fiction in the North Korean Children's Magazine 'Adong Munhak', 1956-1965.” The Journal of Asian Studies, vol. 73, no. 2 (2014): 327-351. https://doi.org/10.1017/S0021911813002404. 